\title{
Municipal Auto-Battery Recycling-Site Leachate Activates Key Enzymes Linked to Non-Insulin Dependent Diabetes Mellitus (NIDDM) and Hypertension
}

\section{Akintunde $\mathrm{JK}^{*}$ and Oboh G}

Functional Foods, Nutraceuticals and Phytomedicine Research Laboratory, Department of Biochemistry, Federal University of Technology, P.M.B., 704, Akure 340001, Nigeria

\begin{abstract}
The rate at which diabetes mellitus and hypertension affect people in the whole world is tremendously increasing due to continuous occupational exposure to complex mixtures of the environment. Therefore, in this study the interaction treatment of municipal auto-battery leachate (MABL) and Elewi-Odo municipal auto-battery recycling-site leachate (EOMABRL), a popular agent for the activation of diabetes and hypertension with key enzymes linked to NIDDM ( $\alpha$-glucosidase and $\alpha$-amylase and hypertension (Angiotensin 1-converting enzyme (ACE) were evaluated. Both types of leachates significantly $(p<0.05)$ activated $\alpha$-glucosidase, $\alpha$-amylase and ACE activities in a dosedependent manner; however, the MABL were stronger activators of $\alpha$-amylase and $\alpha$-glucosidase than EOMABRL. Similarly, the MABL strongly activated Agiotensin 1-converting enzyme (Pro-hypertensive agent) than EOMABRL and significantly $(p<0.05)$ increased malondiadehyde (MDA) production in the pancreas in dose-dependent manner Therefore, increased activity of $\alpha$-glucosidase, $\alpha$-amylase, ACE and induction of lipid peroxidation in battery leachate treated-rat is the mechanism of toxicity through which they induce NIDDM and hypertension.
\end{abstract}

Keywords: Municipal; Battery leachate; a-glucosidase; a-amylase; Hypertension; Diabetes

\section{Introduction}

Diabetes mellitus (DM) has been traced to a variety of different metabolic disorders that involves the inability to produce or use insulin and resulting in elevated plasma glucose (blood sugar) levels. This result in an abnormally high level of glucose in the blood called hyperglycaemia. Diabetes mellitus affects approximately 135 million people in the world and International Diabetes Federation estimated the number of people with diabetes in 2011 already as being 355 millions [1]. However, non-insulin Dependent Diabetes mellitus (NIDDM) is the most common form of diabetes, accounting for $90 \%$ of all cases [2]. Hyperglycaemia is a condition associated with diabetes mellitus. This is primarily linked to most diabetes complications. Hyperglycaemia, if not treated, can lead to serious long-term complications such as kidney failure, blindness, serious skin infection, gangrene, cardiovascular disease, birth effects, strokes, disability and death.

Pancreatic $\alpha$-amylases are glycoside hydrolases which break $\alpha-1$, 4-glycosidic bonds of large polysaccharides (starch) into disaccharides and oligosaccharides prior to the action of a-glucosidases. This eventually breaks down disaccharide and oligosaccharide into monosaccharide (glucose). These glucose units are then absorbed into the blood stream through the epithelia cells of the small intestine [3]. Activation of pancreatic $\alpha$-amylase and glucosidase is the mechanism being adopted to investigate the patients with high blood sugar (hyperglycaemia). The activation of $\alpha$-amylase has been implicated by many agents especially when drugs and dietary foods are incorporated with monovalent anions, notably $\mathrm{NO}_{3}^{-}$or $\mathrm{CIO}_{3}^{-}$and $\mathrm{CI}[4,5]$.

One of the long-term complications of NIDDM is hypertension; Angiotensin-1-converting enzyme (ACE) is an important enzyme involved in maintaining vascular tension. ACE is an exopeptidase secreted mainly by pulmonary and renal endothelial cells which catalyzes the conversion of decapeptide angiotensin I to octapeptide angiotensin II. They are potent direct vasoconstrictors, constricting arteries and veins thereby increasing blood pressure and also function as stimulator of aldosterone [6-8]. Angiotensin II increases thirst sensation (dipsogen) through the subfornical organ (SFO) of the brain. It decreases the response of the baroreceptor reflex, and increases the desire for salt. It also increases secretion of ADH in the posterior pituitary and secretion of ACTH in the anterior pituitary. It equally potentiates the release of nor-epinephrine by direct action on postganglionic sympathetic fibres [9-12]. Numerous drugs had been implicated in hypertension which includes alcohol, amphetamines, ecstasy (MDMA and their derivatives), cocaine, corticosteroids, cyclosporine erythropoietin estrogens (including birth control pills) and other hormones. Many over-the-counter medications such as cough or cold and asthma medications particularly when the cough or cold medicine is taken with certain antidepressants like tranylcypromine or tricyclics, migraine medications and nasal decongestants $[13,14]$. Hence, human predisposition to $\alpha$-amylase and $\alpha$-glucosidase activators suggests a potential risk to people that may come in contact with mixture of contaminants resulting into non-insulin dependent diabetes mellitus (NIDDM).

Environmental pollution from recycling site is a growing problem in many industrialised countries that are generating waste waters. However, waste waters (leachate) from municipal battery recycling site is suspected to contain heavy metals which when indiscriminately

*Corresponding author: Akintunde JK, Functional Foods, Nutraceuticals and Phytomedicine Research Laboratory, Department of Biochemistry, Federal University of Technology, P.M.B., 704, Akure 340001, Nigeria, Fax: +23408064156056; E-mail: akintundejacob@yahoo.com

Received September 29, 2012; Accepted November 28, 2012; Published December 04, 2012

Citation: Akintunde JK, Oboh G (2013) Municipal Auto-Battery Recycling-Site Leachate Activates Key Enzymes Linked to Non-Insulin Dependent Diabetes Mellitus (NIDDM) and Hypertension. J Diabetes Metab 4: 235. doi:10.4172/21556156.1000235

Copyright: (c) 2013 Akintunde JK, et al. This is an open-access article distributed under the terms of the Creative Commons Attribution License, which permits unrestricted use, distribution, and reproduction in any medium, provided the original author and source are credited. 
dumped and not scientifically and properly recycled might have access to water bodies and food chains. They may consequently get into humans and predispose them into metabolic disorders when coming in contact with tissues. This might induce toxicity effects. To explore the effect of environmental pollutions on the development of diabetes and hypertension, it is therefore evident (a) to ascertain the possible effects of municipal battery recycling-site leachate (MABL) on Key Enzymes that are linked to Non-insulin Dependent Diabetes Mellitus (NIDDM) and Hypertension so as to provide the necessary control measures which can obviate the conditions (b) to investigate the possible risk factors which may induce hyperglycaemia or diabetes and hypertension in rats in vitro.

\section{Materials and Methods}

\section{Sampling site and leachate sampling}

The sampling site, Elewi Odo municipal battery recycling site is located on the Ibadan Northern part of Oyo State of Nigeria (latitude $7^{\circ} 25.08^{\prime} \mathrm{N}$ and $7^{\circ} 25.11^{\prime} \mathrm{N}$ and longitudes $3^{\circ} 56.45^{\prime} \mathrm{E}$ and $\left.3^{\circ} 56.42^{\prime} \mathrm{E}\right)$. The site is largely dedicated for auto-battery waste recycling activities. It is close to a nearby stream and situated in the residential estate. It covers about 2 hectares of land. Solid wastes were collected from different points on the site and were thoroughly mixed. It was shredded to provide representative sample in the laboratory. Thereafter, $100 \%$ leachate was extracted and filtered to remove debris using an extraction procedure known as American Society for Testing and Material (ASTM) [15]. The $\mathrm{pH}$ was measured and the sample stored at $4^{\circ} \mathrm{C}$ until use. It was designated Elewi-odo municipal auto-battery recycling site leachate (EOMABRL).

Auto-battery leachate sampling: Eight different auto-batteries were randomly selected from different workshops of Ibadan metropolis, south west, Nigeria. The wet dust was air-dried and shredded to provide representative sample in the laboratory. Thereafter, $100 \%$ was extracted and filtered to remove debris using an extraction procedure known as American Society for Testing and Material (ASTM) [15]. The pH was measured and the sample stored at $4^{\circ} \mathrm{C}$ until use. They were designated as BL1, BL2, BL3, BL4, BL5, BL6, BL7 and BL8. They are collectively regarded as municipal auto-battery leachate (MABL).

Heavy metal analysis: The heavy metal levels of EOMABRL and MABL were determined in accordance with the standard methods Federal Environmental Protection Agency [16], United States Environmental Agency [17], World Health Organisation [18]. The concentration of eleven metals namely $\mathrm{Cu}, \mathrm{Pb}, \mathrm{Cd}, \mathrm{Co}, \mathrm{Cr}, \mathrm{Mo}, \mathrm{Se}, \mathrm{Zn}$, $\mathrm{Fe}, \mathrm{Ni}$ and $\mathrm{Mn}$ were estimated in the leachate sampling using atomic absorption spectrophotometer [19].

\section{Lipid peroxidation assay}

Preparation of tissue homogenates: Healthy male Wistar rats weighing approximately 160-200 g obtained from the Department of Biochemistry, Federal University of Technology Akure, Nigeria were decapitated under mild diethyl ether anaesthesia and the pancreas was rapidly isolated and placed on ice and weighed. This tissue was subsequently homogenized in cold saline $(1 / 10 \mathrm{w} / \mathrm{v})$ with about 10 -upand-down strokes at approximately $1200 \mathrm{rev} / \mathrm{min}$ in a Teflon glass homogenizer. The homogenate was centrifuged for $10 \mathrm{mins}$ at $3000 \times \mathrm{g}$ to yield a pellet that was discarded, and a low-speed supernatant (SI) was kept for lipid peroxidation assay. All the animals received humane care according to the criteria outlined in the 'Guide for the Care and Use of Laboratory Animals' prepared by the National Academy of Science and published by the National Institute of Health. Ethic regulations have been followed in accordance with National and institutional guidelines for the protection of animal welfare during experiments [20].

Lipid peroxidation and thiobarbituric acid reactions: The lipid peroxidation assay was carried out using the modified method [21]. $100 \mu \mathrm{l}$ SI fractions was mixed with a reaction mixture containing $30 \mu \mathrm{l}$ of $0.1 \mathrm{M} \mathrm{pH} 7.4$ Tris- $\mathrm{HCl}$ buffer, extract $(0-100 \mu \mathrm{l})$ and $30 \mu \mathrm{l}$ of $70 \mu \mathrm{M}$ freshly prepared sodium nitroprusside. The volume was made up to $300 \mu \mathrm{l}$ with water before incubation at $37^{\circ} \mathrm{C}$ for $1 \mathrm{~h}$. The colour reaction was developed by adding $300 \mu \mathrm{l} 8.1 \%$ SDS (sodium doudecyl sulphate) to the reaction mixture containing SI, this was subsequently followed by the addition of $600 \mu \mathrm{l}$ of acetic acid/ $\mathrm{HCl}(\mathrm{pH} 3.4)$ mixture and $600 \mu \mathrm{l}$ $0.8 \%$ TBA (Thiobarbituric acid). This mixture was incubated at $100^{\circ} \mathrm{C}$ for $1 \mathrm{~h}$. TBARS (Thiobarbituric acid reactive species) produced were measured at $532 \mathrm{~nm}$ and the absorbance was compared with that of standard curve using MDA (Malondialdehyde).

\section{a-Amylase assay}

Appropriate dilution of the battery-dust and environmental simulated leachates $(500 \mu \mathrm{L}$ was mixed with $500 \mu \mathrm{L}$ of $0.02 \mathrm{M}$ sodium phosphate buffer ( $\mathrm{pH} 6.9$ with $0.006 \mathrm{M} \mathrm{NaCl}$ ) containing Hog pancreatic $\alpha$-amylase (EC 3.2.1.1) $(0.5 \mathrm{mg} / \mathrm{L})$ and then incubated at $25^{\circ} \mathrm{C}$ for 10 mins. Then $500 \mu \mathrm{L}$ of $1 \%$ starch solution in $0.02 \mathrm{M}$ sodium phosphate buffer ( $\mathrm{pH} 6.9$ with $0.006 \mathrm{M} \mathrm{NaCl}$ ) was added to each tube. The reaction mixtures was incubated at $25^{\circ} \mathrm{C}$ for 10 mins and stopped with $1.0 \mathrm{ml}$ of dinitrosalicyclic acid colour reagent. Followed by incubation in a boiling water bath for 5 mins and cooled to room temperature. The reaction mixture was diluted by adding $10 \mathrm{ml}$ of distilled water, and absorbance measured at $540 \mathrm{~nm}$ [22].

\section{a-Glucosidase assay}

Appropriate dilution of the battery-dust and environmental simulated leachates $(50 \mu \mathrm{L}$ and $100 \mu \mathrm{l}$ of $\alpha$-glucosidase solution (1.0 $\mathrm{U} / \mathrm{ml}$ ) in $0.1 \mathrm{M}$ phosphate buffer $(\mathrm{pH} 6.9)$ was incubated at $37^{\circ} \mathrm{C}$ for 10 mins. Then, $50 \mu \mathrm{L}$ of $5 \mathrm{mM}$ p-nitrophenyl- $\alpha$-D-glucopyranoside solution in $0.1 \mathrm{M}$ phosphate buffer ( $\mathrm{pH}$ 6.9) was added. The mixtures were incubated at $37^{\circ} \mathrm{C}$ for $10 \mathrm{mins}$ and diluted by adding $2 \mathrm{ml}$ of distilled water, before reading the absorbance at $400 \mathrm{~nm}$ in the spectrophotometer. The $\alpha$-glucosidase activator activity was expressed as percentage activation [23].

\section{Angiotensin 1 Converting Enzyme (ACE) assay}

A mixture of appropriate dilution of the battery-dust and environmental simulated leachates $(50 \mu \mathrm{L})$ and ACE solution $(50 \mu \mathrm{L}$, $4 \mathrm{mU}$ ) was incubated at $37^{\circ} \mathrm{C}$ for 15 mins. The reaction was initiated by adding $150 \mu \mathrm{L}$ of $8.33 \mathrm{mM}$ of the substrate Bz-Gly-His-Leu in 125 $\mathrm{mM}$ Tris- $\mathrm{HCl}$ buffer ( $\mathrm{pH} \mathrm{8.3)} \mathrm{to} \mathrm{the} \mathrm{mixture.} \mathrm{After} \mathrm{incubation} \mathrm{for} 30$ mins at $37^{\circ} \mathrm{C}$, the reaction was stopped by adding $250 \mu \mathrm{L}$ of $1 \mathrm{M} \mathrm{HCl}$. The Bz-Gly produced by the reaction was extracted with $1.5 \mathrm{ml}$ ethyl acetate. The mixture was centrifuged to separate the ethyl acetate layer; and $1 \mathrm{ml}$ of the ethyl acetate layer was transferred to a cleaned test tube and evaporated. The residue was re-dissolved in distilled water and its absorbance was measured at $228 \mathrm{~nm}$ [24].

\section{Data analysis}

The results of the replicates were pooled and expressed as mean \pm standard deviation. Student $t$-test, one way analysis of variance (ANOVA) and the least significance difference (LSD) were carried out. Significance was accepted at $\mathrm{p} \leq 0.05$ [25]. 
Citation: Akintunde JK, Oboh G (2013) Municipal Auto-Battery Recycling-Site Leachate Activates Key Enzymes Linked to Non-Insulin Dependent Diabetes Mellitus (NIDDM) and Hypertension. J Diabetes Metab 4: 235. doi:10.4172/2155-6156.1000235

Page 3 of 6

\section{Results and Discussion}

First, the proximate composition (chemical components) of heavy metals in MABL and EOMABRL were investigated and the results are presented in tables 1-3. The results revealed that MABL showed high significant level $(\mathrm{p}<0.05)$ of heavy metals than EOMABRL. Also, both are higher than the permissible regulatory levels in the drinking water as recommended by NAFDAC, USEPA, FEPA and WHO (Tables 1-3). The ability of MABL and EOMABRL to activate $\alpha$-glucosidase activity in vitro was also investigated and the results are presented in figures 1 and 2 . The results revealed that the leachates significantly activated a-glucosidase in a dose-dependent manner (in the range of 0-200 $\mu \mathrm{g} /$ ml). MABL exhibited higher activity than EOMABRL. This may be linked to high elevation of heavy metals contained in the leachates.

\begin{tabular}{|c|c|c|c|c|c|}
\hline \multicolumn{6}{|c|}{ Type of battery leachate (MABL) } \\
\hline Parameter & BL1 & BL2 & BL3 & BL4 & BL5 \\
\hline $\mathrm{pH}$ & 3.29 & 2.14 & 2.34 & 1.56 & 6.29 \\
\hline Cadmium & $1.417 \pm 0.06$ & $1.410 \pm 0.00$ & $1.417 \pm 0.06$ & $1.427 \pm 0.21$ & $1.413 \pm 0.06$ \\
\hline Cobalt & $1.847 \pm 0.06$ & $1.850 \pm 0.20$ & $1.837 \pm 0.12$ & $1.827 \pm 0.32$ & $1.837 \pm 0.15$ \\
\hline Chromium & $24.1 \pm 15.59$ & $23.467 \pm 5.03$ & $29.533 \pm 8.51$ & $11.3 \pm 13.53$ & $20.433 \pm 7.62$ \\
\hline Copper & $2.783 \pm 2.41$ & $3.277 \pm 1.88$ & $2.44 \pm 2.63$ & $2.437 \pm 1.33$ & $2.18 \pm 1.06$ \\
\hline Iron & $1.77 \pm 0.40$ & $2.323 \pm 1.01$ & $1.76 \pm 0.36$ & $1.83 \pm 1.73$ & $1.733 \pm 0.15$ \\
\hline Manganese & $1.853 \pm 0.12$ & $1.833 \pm 0.12$ & $18.57 \pm 0.15$ & $1.84 \pm 0.17$ & $1.85 \pm 0.17$ \\
\hline Molybdenum & $2.017 \pm 0.45$ & $2.010 \pm 0.20$ & $2.027 \pm 0.15$ & $2.073 \pm 0.92$ & $2.0 \pm 0.20$ \\
\hline Nickel & $2.277 \pm 0.67$ & $2.517 \pm 0.15$ & $2.267 \pm 0.15$ & $2.257 \pm 1.25$ & $2.193 \pm 0.32$ \\
\hline Lead & $8.167 \pm 2.60$ & $9.383 \pm 6.19$ & $7.35 \pm 1.93$ & $27.9 \pm 17.00$ & $12.1 \pm 3.61$ \\
\hline Selenium & $2.023 \pm 0.72$ & $2.057 \pm 0.84$ & $2.023 \pm 0.55$ & $2.233 \pm 3.20$ & $2.043 \pm 0.34$ \\
\hline Zinc & $1.757 \pm 0.06$ & $2.277 \pm 0.40$ & $1.758 \pm 0.06$ & $1.757 \pm 0.21$ & $1.747 \pm 0.06$ \\
\hline
\end{tabular}

Values are significantly higher $(P<0.05)$ against the NAFDAC, USEPA, FEPA and WHO, $n=3$. Values are measured in part per million (ppm)

Table 1: Characterization of proximate heavy metals (Chemical components) of Municipal auto- battery Leachate (MABL).

\begin{tabular}{|l|l|l|l|}
\hline \multicolumn{2}{|c|}{} & \multicolumn{2}{l|}{ Type of battery leachate (MABL) } \\
\hline Parameter & BL6 & BL7 & BL8 \\
\hline $\mathrm{pH}$ & 3.97 & 3.38 & 1.51 \\
\hline Cadmium & $1.333 \pm 1.42$ & $1.413 \pm 0.06$ & $1.417 \pm 0.06$ \\
\hline Cobalt & $1.847 \pm 0.42$ & $1.857 \pm 0.21$ & $1.867 \pm 0.06$ \\
\hline Chromium & $22.3 \pm 23.39$ & $30.0 \pm 15.59$ & $21.833 \pm 4.16$ \\
\hline Copper & $2.63 \pm 1.21$ & $2.377 \pm 1.36$ & $28.4 \pm 9.64$ \\
\hline Iron & $1.67 \pm 0.90$ & $1.777 \pm 0.49$ & $5.04 \pm 2.34$ \\
\hline Manganese & $1.85 \pm 0.17$ & $1.843 \pm 0.12$ & $1.837 \pm 0.15$ \\
\hline Molybdenum & $2.01 \pm 0.44$ & $2.023 \pm 0.15$ & $2.037 \pm 0.12$ \\
\hline Nickel & $2.057 \pm 2.94$ & $2.23 \pm 0.46$ & $2.458 \pm 0.49$ \\
\hline Lead & $10.813 \pm 8.80$ & $5.07 \pm 0.89$ & $7.14 \pm 2.61$ \\
\hline Selenium & $1.673 \pm 2.63$ & $1.957 \pm 0.95$ & $2.25 \pm 2.04$ \\
\hline Zinc & $1.8 \pm 1.39$ & $1.897 \pm 0.15$ & $2.92 \pm 0.52$ \\
\hline
\end{tabular}

Values are significantly higher $(P<0.05)$ against the NAFDAC, USEPA, FEPA and WHO, $n=3$. Values are measured in part per million $(p p m)$

Table 2: Characterization of proximate heavy metals (Chemical components) of Municipal auto- battery Leachate (MABL).

\begin{tabular}{|c|c|c|c|c|c|}
\hline Parameter & EOMABRL & $\begin{array}{l}\text { NAFDAC } \\
\text { (Max. accept) }\end{array}$ & $\begin{array}{l}\text { USEPA } \\
\text { (Max. accept) }\end{array}$ & $\begin{array}{l}\text { FEPA } \\
\text { (Max. accept) }\end{array}$ & $\begin{array}{l}\text { WHO } \\
\text { (Max. accept) }\end{array}$ \\
\hline $\mathrm{pH}$ & $2.56^{*}$ & 7.0 & $6.5-8.5$ & $6-9$ & $7-9$ \\
\hline Cadmium & $0.006^{*}$ & 0.0 & 0.005 & 0.05 & 0.003 \\
\hline Cobalt & $0.049^{*}$ & 0.0 & - & - & - \\
\hline Chromium & $0.068^{*}$ & 0.0 & 0.1 & 0.05 & 0.005 \\
\hline Copper & $0.341^{*}$ & 0.0 & 1.0 & 0.3 & - \\
\hline Iron & $2.66^{*}$ & 0.0 & 0.3 & 0.05 & - \\
\hline Manganese & $7.84^{*}$ & 0.0 & 0.05 & 0.05 & - \\
\hline Molybdenum & ND & - & - & - & - \\
\hline Nickel & $0.048^{*}$ & - & - & - & - \\
\hline Lead & $0.015^{\star}$ & 0.0 & 0.01 & 0.01 & 0.01 \\
\hline Selenium & ND & - & - & - & - \\
\hline Zinc & $1.26^{*}$ & 5.0 & - & - & 5.0 \\
\hline Total Alkalinity & $145^{\star}$ & - & 20 & 250 & - \\
\hline P04- & $0.1^{*}$ & - & - & - & - \\
\hline
\end{tabular}

$\left({ }^{*} \mathrm{P}<0.05\right)$ against NAFDAC, USEPA, FEPA and $\mathrm{WHO}, \mathrm{n}=3$. Values are measured in part per million $(\mathrm{ppm})$

Table 3: Characterization of heavy metals (chemical components) in Elewi Odo Municipal auto-battery recycling site leachate (EOMABRL). 
The activity of $\alpha$-glucosidase of our present study was in agreement with some earlier reports where some trace elements have been implicated in many adverse health effects. It was reported that heavy metal (pollutant) damage organ functions and disrupt physiological homeostasis. Also, the efficiency of some essential trace metals plays a contributory role in the development of diabetes mellitus. Some toxic metals such as Zinc, arsenic, cadmium, mercury and nickel have also been shown to be elevated in biological samples of diabetes mellitus patients [26], which are known as environmental risk factors. In addition, the research had shown that levels of all these metals were significantly higher in the women with diabetes and their infants than in the women without diabetes and their infants [27]. Our present data suspect that these metals may be responsible for the development of diabetes II (non-insulin dependent). This may be by activating the functional enzyme, $\alpha$-glucosidase which breaks down disaccharides and oligosaccharides into monosaccharides (glucose), which eventually result into hyperglycaemia.

Furthermore, the ability of the MABL and EOMABRL to activate $\alpha$-amylase activity in vitro was investigated and the results are presented in figures 3 and 4. MABL and EOMABRL exhibited a dose-dependent increase in the activity of alpha amylase in the range of $0-200 \mu \mathrm{g} / \mathrm{ml}$. MABL exhibited significantly $(\mathrm{p}<0.05)$ higher alpha amylase activity than EOMABRL. This high activation potential may be attributed to marked elevated levels of heavy metals in the leachate

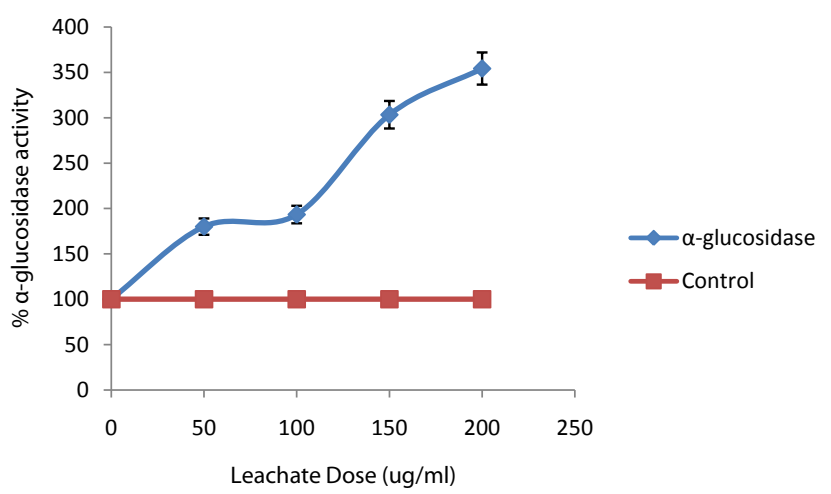

Figure 1: Effect of Elewi Odo Municipal auto-battery recycling-site leachate (EOMABRL) on a-glucosidase activity. Values represent mean \pm standard deviation. Values are significantly higher $(p<0.05)$ against the control, $n=3$.

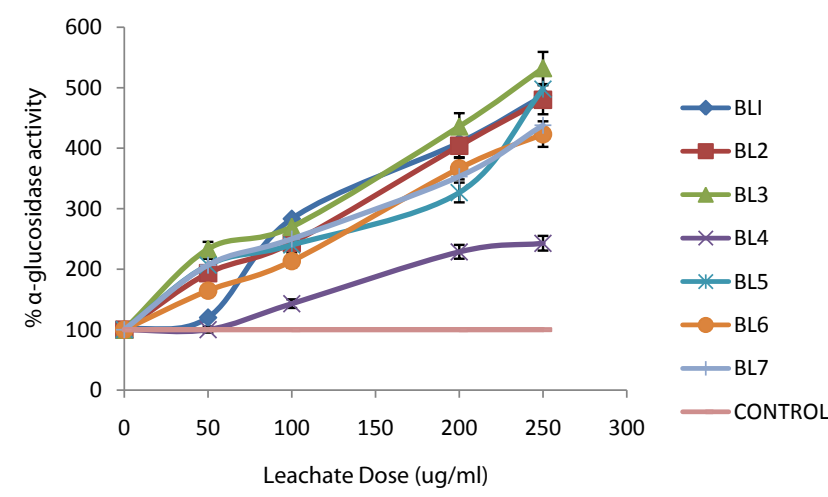

Figure 2: Effect of Municipal auto-battery leachate (MABL) on $\alpha$-glucosidase activity. Values represent mean \pm standard deviation, $n=3$. Values are significantly higher $(p<0.05)$ compared with the control.

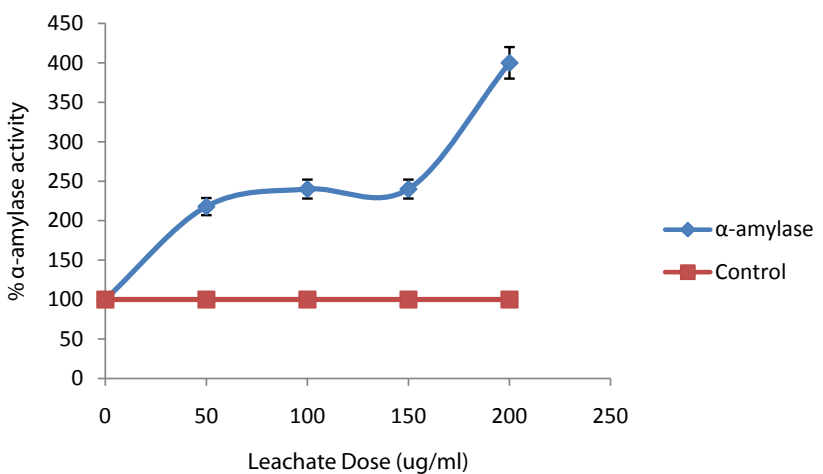

Figure 3: Effect of Elewi Odo Municipal auto-battery recycling-site leachate (EOMABRL) on $\alpha$-Amylase activity. Values represent mean \pm standard deviation. Values are significantly higher $(p<0.05)$ against the control, $n=3$.

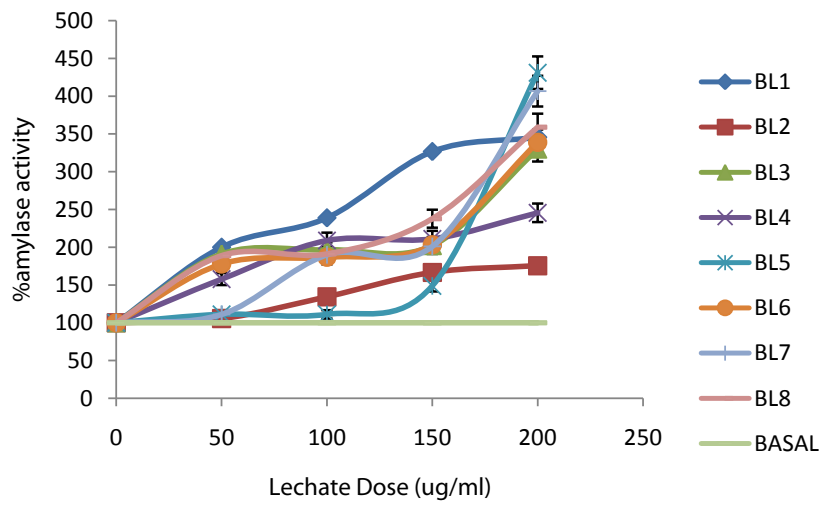

Figure 4: Effect of Municipal auto-battery recycling-site leachate (MABL) on a-Amylase activity. Values represent mean \pm standard deviation. Values are significantly higher $(p<0.05)$ against the control, $n=3$.

(Tables 1-3). This increases the alpha amylase activity by breaking $\alpha-1$, 4-glycosidic bonds of large polysaccharides (starch) into disaccharides and oligosaccharides. Our present result is consistent with the earlier reports which recorded that heavy metals are potent enzyme activators by acting as prosthetic groups of the enzymes [28].

Hence, the present study suggests that MABL and EOMABRL are mild activators of $\alpha$-glucosidase and strong activators of $\alpha$-amylase. Stronger activation of the enzyme activity could induce hyperglycaemia (excess blood glucose level in the blood). Our present investigation corroborates with the previous observation that drugs and dietary foods containing divalent cations activate $\alpha$-amylase $[4,5]$. Also, in humans, diabetogenic process appears to be caused by immune destruction of the beta cells. Diabetes can be produced in animals by the drugs alloxan and streptozocin. This causes the production of active oxygen species. Not only are oxygen radicals involved in the cause of diabetes, they also play roles during the complication of long term treatment of diabetes. This study suggests that the sample can induce oxygen radicals which reduce intrinsic antioxidant properties. These leachates are regarded as environmental toxicants and diabetonic agent evoking hyper-triglycaemia and some other abnormalities when treated with pancreatic amylase [24].

Angiotensing 1-converting enzyme (ACE) cleaves angiotensin 1 to produce angiotensin II, a powerful vasoconstrictor that has been 
Citation: Akintunde JK, Oboh G (2013) Municipal Auto-Battery Recycling-Site Leachate Activates Key Enzymes Linked to Non-Insulin Dependent Diabetes Mellitus (NIDDM) and Hypertension. J Diabetes Metab 4: 235. doi:10.4172/2155-6156.1000235

Page 5 of 6

identified as major factor in vascular hypertension [7,8]. Therefore, ACE activators have been widely developed to increase angiotensin II production in cardiovascular diseases, and utilized in clinical applications. As shown in figures 5 and 6, EOMABRL activated ACE activity in a dose-dependent manner. The activity of ACE was significantly $(p<0.05)$ higher activity than EOMABRL at the range of $0-25 \mu \mathrm{g} / \mathrm{ml}$. The result clearly suggests that MABL and EOMABRL are possible ACE activators. This could explain the possible mechanism for which hypertension could be induced. This study is in accordance with the reports that xanthenone and resorcinol naphthalein (known as toxicants) enhanced ACE activity of the exposed rat-in vitro [29]. To this effect, high blood pressure has been linked to heavy metal toxicity [30].

In order to elucidate the possibility that MABL and EOMABRL interfere with the structural cell membrane of pancreas and thereby induces lipid membrane damage in rats, the level of lipid degradation products, a maker of lipid peroxidation was evaluated and the results are shown in figures 7 and 8 . Pancreatic tissue treated with MABL and EOMABRL caused a significant $(\mathrm{p}<0.05)$ increase in the MDA content in a dose-dependent manner, showing high levels of MDA than EOMABRL. This discovery may be connected with high quantity of complex mixtures especially heavy metals in the leachates. This finding

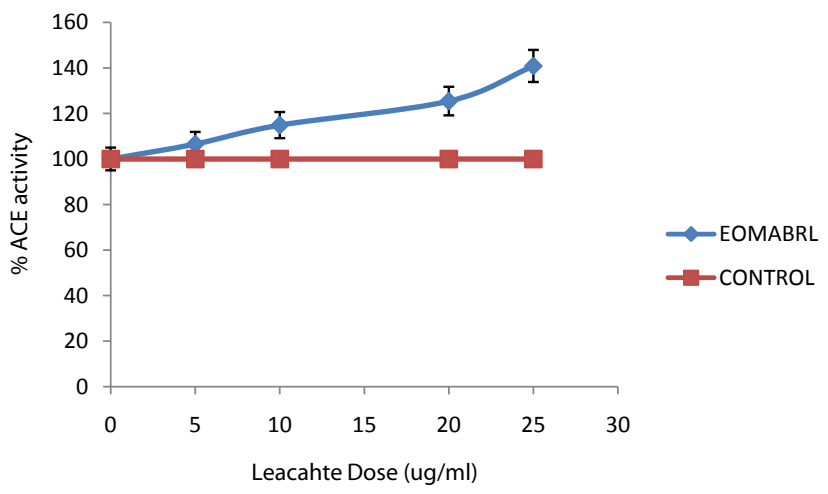

Figure 5: Effect of Elewi Odo Municipal auto-battery recycling-site leachate (EOMABRL) on Angiotensin-converting enzyme activity (ACE) Values represent mean \pm standard deviation. Values are significantly higher $(p<0.05)$ against the control, $n=3$.

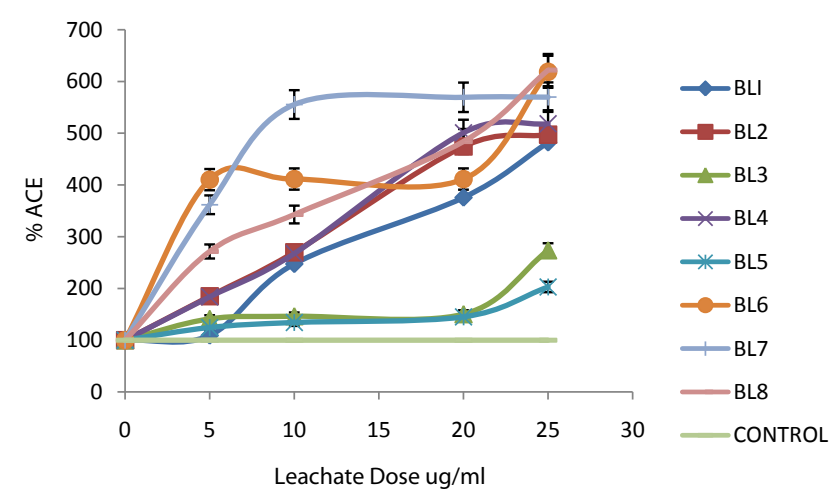

Figure 6: Effect of Municipal auto-battery leachate (MABL) on Angiotensinconverting enzyme activity (ACE).Values represent mean \pm standard deviation, $n=3$. Values are significantly higher $(p<0.05)$ compared with the control. is consistent with reports that complex mixtures of municipal landfill leachate induced lipid peroxidation rat's liver by compromising the integrity of cell membrane, resulting in lipid membrane damage [31] Also, it had been reported that cadmium ingestion in food, drinking water and vaccine can have direct toxic effects on the pancreas and intestine, which may be a risk factor in development of type II diabetes and hypertension. Thus, it may be plausible to suggest that battery recycling-site leachate contains constituents which can induce types II diabetes and hypertension in rat. This suggests a potential risk to humans that may come in contact with this mixture of contaminants since pancreatic enzymes are universal to all mammals.

\section{Conclusion}

This study showed that the high activity of key enzymes linked to non-insulin diabetes mellitus ( $\alpha$-glucosidase and $\alpha$-amylase) and hypertension (Angiotensin 1-converting enzyme (ACE)) and induction of lipid peroxidation by MABL and EOMABRL could be part of mechanism through which the leachate (water table pollutant) induce type 2 diabetes and hypertension. Similarly, the strong $a$-amylase activation and mild activation of $\alpha$-glucosidase suggest it as a potent risk factor of hypertension and postprandial hyperglycaemia associated with type 2 diabetes.

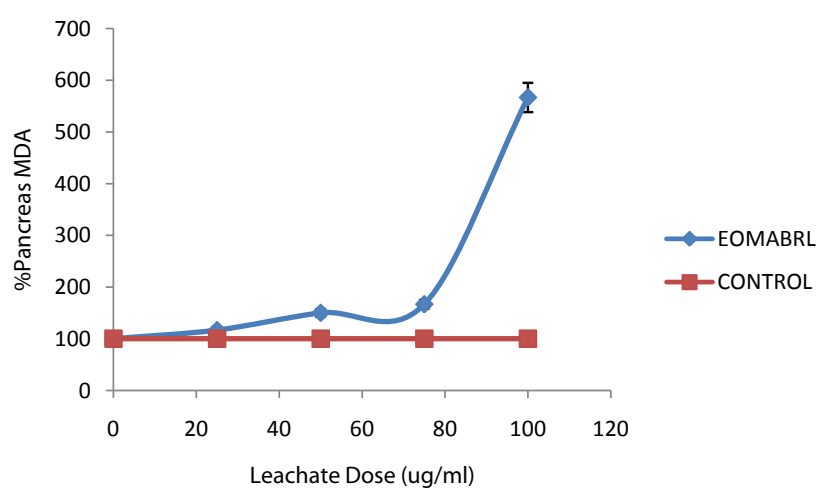

Figure 7: Induced lipid peroxidation in pancreas by Elewi Odo Municipal auto-battery recycling-site leachate (EOMABRL). Thiobarbituric acid reactive species (TBARS) produced were measured at $532 \mathrm{~nm}$ and the absorbance was compared with that of standard using \% Pancreas MDA (Malondiadehyde). Values are significantly higher $(p<0.05)$ against the control.

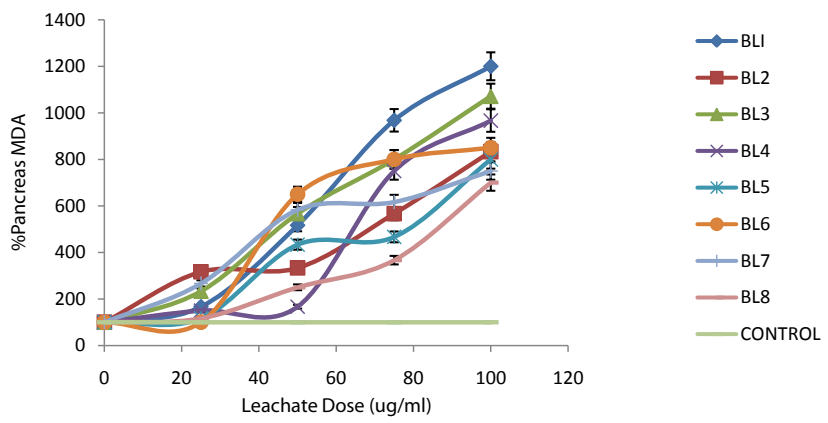

Figure 8: Induced lipid peroxidation in Pancreas by auto-battery leachates (MABL). Thiobarbituric acid reactive species (TBARS) produced were measured at $532 \mathrm{~nm}$ and the absorbance was compared with that of standard using \% Pancreas MDA (Malondiadehyde). Values are significantly higher $(p \leq 0.05)$ compared with the control. 
Citation: Akintunde JK, Oboh G (2013) Municipal Auto-Battery Recycling-Site Leachate Activates Key Enzymes Linked to Non-Insulin Dependent Diabetes Mellitus (NIDDM) and Hypertension. J Diabetes Metab 4: 235. doi:10.4172/2155-6156.1000235

Page 6 of 6

\section{References}

1. Kwon YI, Apostolidis E, Kim YC, Shetty K (2007) Health benefits of traditional corn, beans, and pumpkin: in vitro studies for hyperglycemia and hypertension management. J Med Food 10: 266-275.

2. Chakrabarti R, Rajagopalan R (2002) Diabetes and insulin resistance associated disorders: Disease and the therapy. Curr Sci Assoc 83: 1533-1538.

3. Abesundara KJ, Matsui T, Matsumoto K (2004) Alpa-glucosidase inhibitory activity of some Sri Lanka plant extracts, one of which, Cassia auriculata, exerts a strong anti-hyperglycaemic effects in rats comparable to the therapeutic drug acarbose. Journal of Agricultural and Food chemistry 52: 2541-2545.

4. Kimmel B, Inzucchi SE (2005) Oral agents for type 2 diabetes: An update. Clin Diab 23: 64-76.

5. Kim JS, Kwon CS, Son KH (2000) Inhibition of alpha-glucosidase and amylase by luteolin, a flavonoid. Biosci Biotechnol Biochem 64: 2458-2461.

6. Kiezenbaum, Abraham L (2007) Histology and cell biology: an introduction to pathology.

7. Zhang R, Xu X, Chen T, Li L, Rao P (2000) An assay for angiotensin-converting enzyme using capillary zone electrophoresis. Anal Biochem 280: 286-290.

8. SKEGGS LT Jr, KAHN JR, SHUMWAY NP (1956) The preparation and function of the hypertensin-converting enzyme. J Exp Med 103: 295-299.

9. Basso N, Terragno NA (2001) History about the discovery of the reninangiotensin system. Hypertension 38: 1246-1249.

10. Williams GH, Dluhy RG (2008) Chapter 336: Disorders of the Adrenal Cortex. Harrison's principles of internal medicine. McGraw-Hill Medical. ISBN 0-07146633-9.

11. Skurk T, Lee YM, Hauner $H$ (2001) Angiotensin II and its metabolites stimulate PAl-1 protein release from human adipocytes in primary culture. Hypertension 37: $1336-1340$.

12. Gesualdo L, Ranieri E, Monno R, Rossiello MR, Colucci M, et al. (1999) Angiotensin IV stimulates plasminogen activator inhibitor-1 expression in proximal tubular epithelial cells. Kidney Int 56: 461-470.

13. Kaplan NM (2007) Systemic hypertension: therapy. Braunwald's Heart Disease: A Textbook of Cardiovascular Medicine. (8thedn), Saunders Elsevier 41.

14. Victor RG, Kaplan NM (2007) Systemic hypertension: mechanisms and diagnosis. In: Libby P, Bonow RO, Mann DL, Zipes DP. Braunwald's Heart Disease: A Textbook of Cardiovascular Medicine. (8thedn), Saunders Elsevier 48.

15. Perket CL, Krueger JR, White Hurst DA (1982) The use of extraction test for deciding waste disposal options. Trends in Anal Chem 1: 342-347.

16. Federal Environmental Protection Agency (FEPA) (2001) Federal Ministry of
Environment. National Guidelines and Standards for Water in Nigeria. Lagos, Nigeria: Diversified resources.

17. USEPA (1996) Test Methods for Evaluating Solid Waste. Vol 1A: Laboratory Manual Physical/Chemical Methods, SW 846 (3rdedn), U.S Gov. Print, Office Washington D.C.

18. La Vignera S, Condorelli RA, Vicari E, D’Agata R, Salemi M, et al. (2012) High levels of lipid peroxidation in semen of diabetic patients. Andrologia 44: 565570 .

19. AOAC (1990) Official methods of analysis. (15thedn), Association of official Analytical chemists, Washington, DC

20. U.S. National Institutes of Health (1985) Laboratory animal welfare: Public Health Service policy on humane care and use of laboratory animals by awardee institutions; notice. Fed Regist 50: 19584-19585.

21. Ohkawa H, Ohishi N, Yagi K (1979) Assay for lipid peroxides in animal tissues by thiobarbituric acid reaction. Anal Biochem 95: 351-358.

22. Worthington Biochemical Corp (1978) Worthington, enzyme and related biochemical. Worthington Biochemical Corp.

23. Apostolidis E, Kwon YI, Shetty K (2007) Inhibitory potential of herb, fruit and fungal-enriched cheese against key enzymes linked to type 2 diabetes and hypertension. Inn Food Sci Emerg Tecchnol 8: 46-54.

24. Cushman DW, Cheung HS (1971) Spectrophotometric assay and properties of the Angiotensin-converting enzyme of rabbit lung. Biochem Pharmacol 20: 1637-1648.

25. Zar JH (1984) Biostatistical Analysis, Prentice-Hall, Inc. USA: 620.

26. Chen YW, Ching YY, Chun FH, Dong ZH, Yuk ML, et al. (2009) Heavy metal, Islet function and Diabetes development. Islets 1: 169-176.

27. Kolachi NF, Kazi TG, Afridi HI, Kazi N, Khan S, et al. (2011) Status of toxic metals in biological samples of diabetic mothers and their neonates. Biol Trace Elem Res 143: 196-212.

28. Manabe S, Wada O (1981) Triphenyltin fluoride (TPTF) as a diabetogenic agent. TPTF induces diabetic lipemia by inhibiting insulin secretion from morphologically intact rabbit B-cell. Diabetes 30: 1013-1021.

29. WHD (2008) ISH and Three New Classes of Antihypertensive Drugs: Identification of Angiotensin-Converting Enzyme-2 Activators as Potential Antihypertensive Drugs.

30. Houston MC (2007) The role of mercury and cadmium heavy metals in vascula disease, hypertension, coronary heart disease, and myocardial infarction. Altern Ther Health Med 13: S128-S133.

31. Farombi EO, Akintunde JK, Nzute N, Adedara IA, Arojojoye O (2012) Municipa landfill leachate induces hepatotoxicity and oxidative stress in rats. Toxicol Ind Health 28: 532-541. 